Council has also been concerned with the completion of the application of the recommendations of the Carpenter report to scientific establishments, and in his presidential address at the annual meeting on April 29, Sir Richard Redmayne emphasized the necessity for the upgrading of the highest professional and scientific posts in the Civil Service, which, so far as remuneration is concerned, compare most unfavourably with posts carrying a similar responsibility outside the Service. A sub-committee is considering appropriate salaries for those professional posts outside the scope of arbitration with the view of making representations to the authorities. The Association is also dealing with the salaries of architects, engineers and surveyors in the Civil Service. Sir Richard criticized the Treasury for refusing to allow the reference to arbitration of the Institution's claim that women scientific officers should receive the same scales of pay as their male colleagues in the same grade, and stated that the Chancellor of the Exchequer had been asked to receive a deputation on this question.

\section{Fruit Supplies in 1936}

THE Intelligence Branch of the Imperial Economic Committee has issued a volume dealing with fruit supplies during 1936 (H.M. Stationery Office, pp. 106. 28. $6 d$. net or $2 s .9 d$. post free). 55 per cent of the total import of fruit was of Empire origin. So high a proportion has never before been reached. There are, however, some very potent lessons for the home producer. The present report gives the convincing information that each apple tree yielded an average of $12 \cdot 7 \mathrm{lb}$. of fruit in 1935 , and $68 \cdot 3 \mathrm{lb}$. in 1936 . The "untimely and unusually severe frost" in May of 1935 is mentioned as the main cause of that season's low yield. It cannot be emphasized too strongly that the effects of frost are now largely within the control of the grower. The pioneer work of Mr. George Harrington, the investigations into general principles by various scientific workers, and the practical experiments by the technical staff of Messrs. Geo. Monro, Ltd., have made the practice of orchard heating a practical proposition without heavy finance. Total imports of raw fruit into the United Kingdom remain fairly steady around an average of nearly $28,000,000$ cwt.. and apple imports are not very variable around a mean of about 6,500,000 cwt. Imports of grapes, peaches, lemons, pineapples and plums from Empire sources were higher in 1936 than ever before, and more bananas were imported by Great Britain than in any previous year. Supplies of fruit from South Africa reached a new record. Totals for most fruit imports were, however, lighter than in 1935 .

\section{The Ross Institute}

A meering of the Industrial Advisory Committee of the Ross Institute, which is now incorporated with the London School of Hygiene and Tropical Medicine, was held on May 28, at which the activities of the Institute were surveyed. Useful discussions also ensued upon the housing of African labour, the risk of malaria when replanting rubber, the Indore process of disposal of night soil and town refuse and courses of instruction for laymen proceeding to the tropics. Information was also given of an investigation by Dr. Crowden at the School of Hygiene of experiments on air-conditioned cubicles for use in the tropics.

\section{Fast Atlantic Crossing by Air}

The Empire flying-boat Cambria crossed the Atlantic on September 28 in the fastest time ever recorded. The distance of 2,000 miles from Newfoundland to Foynes, near Limerick, was covered in $10 \mathrm{hr} .36 \mathrm{~min}$., giving an average speed of 190 miles an hour. According to the account in The Times of September 29, Captain G. J. Powell made tests of speed at various altitudes. During the first part of the flight he remained at 4,000-5,000 ft. and made speeds of $172 \cdot 6-185$ m.p.h. Later he climbed to 7,000 ft. and attained a speed of 195 m.p.h. Bad weather then forced him to $13,000 \mathrm{ft}$. when his speed fell to 167 m.p.h. Eventually, he reduced the height to $10,000 \mathrm{ft}$., where the most favourable wind for the easterly part of the journey was found.

\section{The Night Sky in October}

Summer Time ends on October 3 at $2^{\text {h }}$ U.T. The moon is new on October 4 at $12 \cdot 0^{\mathrm{h}}$ and full (the Hunter's Moon) on October 19 at $21 \cdot 8^{\mathrm{h}}$. Conjunctions between the moon and the planets occur as follows: Venus on October 2 at $4^{\mathrm{h}}$; Mercury on October 3 at $6^{\mathrm{h}}$; Mars on October 11 at $18^{\mathrm{h}}$; Jupiter on October 12 at $17^{\mathrm{h}}$ and Saturn on October 18 at $8^{\mathrm{h}}$. On October 29 at $17^{\mathrm{h}}$, Mars and Jupiter are in conjunction; the two planets passing within $1 \frac{1}{2}^{\circ}$ of one another (heliocentric positions). On October 11 at $6^{\mathrm{h}}$, Venus is in conjunction with Neptune. On October 15 , Uranus is near the sixth magnitude star o Arietis ; the diameter of the planet is $3 \frac{1}{2}$ ". The satellites of Jupiter, which always offer an attractive field for observation, present a few special features this month. On October 5 at $2^{\mathrm{h}} 24^{\mathrm{m}}-27^{\mathrm{m}}$ Satellite II will be partly eclipsed by Satellite I. On October 7 a similar eclipse of these two satellites takes place at $22^{\mathrm{h}} 07^{\mathrm{m}}-24^{\mathrm{m}}$, the magnitude of the eclipse being $0 \cdot 4$. On October 17, I is partially eclipsed by III at $3^{\mathrm{h}} 27^{\mathrm{m}}-36^{\mathrm{m}}$. Appulses between II and I occur on October $12^{\mathrm{d}} 01 \cdot 9^{\mathrm{h}}$ and October $22^{\mathrm{d}} 1 \cdot 0^{\mathrm{h}}$, whilst a complete occultation of II by I will take place on October $25^{\mathrm{d}} 17 \cdot 9^{\mathrm{m}}$. On October 13, Jupiter will occult the seventh magnitude star B.D. $-22^{\circ} 5100=$ C.D. 13939, the emersion being visible in Great Britain at $18^{\mathrm{h}} 34^{\mathrm{m}}$ at position angle $276^{\circ}$ from the north point of the planet's image ("B.A.A. Handbook, 1937 ", p. 19). The light variation of Algol ( $\beta$ Persei) may be observed about $1 \frac{1}{2}$ hours before and after the following times: October $3^{\mathrm{d}} 19 \cdot 6^{\mathrm{h}} ; 18^{\mathrm{d}} 03 \cdot 7^{\mathrm{h}} ; 21^{\mathrm{d}} 00 \cdot 5^{\mathrm{h}}$ and $23^{\mathrm{d}} \mathbf{2 1} \cdot 3^{\mathrm{h}}$. The periodic comet, Encke, which was re-discovered by Jeffers on September 3 at the Lick Observatory, passes from Triangulum to Andromeda during the month. The comet, which was of magnitude 18 at the time of discovery, is still very 
faint, its anticipated magnitude at perihelion on December 27 being about $5 \cdot 5$. An ephemeris for this comet is given by Dr. A. C. D. Crommelin in "B.A.A. Handbook", p. 34; corrections to this ephemeris are given by L. E. Cunningham, using the positions obtained by Jeffers at re-discovery. The zodiacal light may be seen before dawn in the first part of the month when the moon is absent. In view of the present general high level of solar activity, the northern skies may also be scanned for the presence of auroral light.

\section{Announcements}

H.M. QUeEn Mary has once again shown the keen interest she takes in the higher education of women by promising to visit the Royal Holloway College (University of London) at Egham on October 12. H.R.H. Princess Alice is chairman of the governors of this women's College, which has about two hundred students, and she shows a highly practical interest in the College and in the careers of its students. It is worthy of mention that during the university year just closing a student of Royal Holloway College, Miss Gladys E. Muddle, gained the Sherbrooke Studentship and the Sir John William Lubbock Memorial Prize, open to all students of mathematics in the University of London.

Sir Thomas Holland, principal of the University of Edinburgh, and formerly director of the Geological Survey of India, has accepted the presidency of the Geographical Association for 1938.

The Le Chatelier Memorial Lecture of the Chemical Society will be delivered on October 28 at 5.30 p.m. by Dr. C. H. Desch, superintendent of the Metallurgical Department, National Physical Laboratory.

The Sex Education Society has issued a programme of seven lectures to be given at the Conway Hall, Red Lion Square, W.C.1, during the present session. The first will be delivered by the president, Dr. Norman Haire, at 8 p.m. on October 5. The full programme can be obtained from the Honorary Secretary, 27 Harley Street, W.1.

THE Annual Conference of Greenkeepers will be held at St. Ives Research Station, Bingley, Yorkshire, on October 19. During the morning, a tour of the Research Station will be made, and during the afternoon a series of short papers will be given. A course on scientific greenkeeping will be held on October 20-26. The course will include non-technical lectures by members of the staff of the Research Station, coupled with practical work and demonstrations on the experiment ground. Further information can be obtained from the Director, St. Ives Research Station, Bingley.

The British Drug Houses, Ltd., Graham Street, London, N.1, have issued a new edition of their booklet dealing with B.D.H. standard stains, and including also a full range of the various materials required by the microscopist; the booklet may be obtained free on application. Useful notes are appended upon the bacteriological, histological and pathological applications of the various stains and materials, most of which can be supplied in small quantities suited to the requirements of the individual worker.

Dr. S. C. Bracktin writes to point out that an error occurs in the short article contributed by Dr. J. S. Owens to NATURE of August 21 upon his "Electrotor Smoke and Dust Meter". The article was based solely upon a paper by Dr. Blacktin in the Journal of Industrial Hygiene and Toxicology, and not upon an examination of the instrument itself. Referring to the insertion of a new record disk, the words were used "and the cap with its disk screwed into position". Dr. Blacktin points out that this was a misunderstanding of the statement made in his paper; for the record disk is not supported inside the cap of the instrument but on a table under it.

The Academy of Sciences of Cuba has recently celebrated the seventy-fifth anniversary of its foundation.

A CHAIR of social medicine has recently been created in the University of Paris. Its incumbent will initiate fifth-year students into certain elements of preventive medicine such as sickness insurance.

Dr. John E. Gordon, field director of the International Health Division of the Rockefeller Founda tion, New York, has been appointed professor of preventive medicine and epidemiology at Harvard University Medical School.

The John and Mary R. Markle Foundation of New York has presented one hundred thousand dollars to the National Research Council for the support of research in endocrinology in the next three years. The fund will be administered by the Division of Medical Sciences.

As the result of years of agitation by social re. formers, no marriage will be possible in the Argentine in future unless the bridegroom is able to present to the civil authorities a certificate that he is free from contagious diseases transmissible in wedlock. The law, which is to be enforced immediately, does not apply to women. Other clauses in the law provide for the compulsory hospitalization of refractory cases of contagious infection and the closing of houses of ill-fame.

Erratum. In the obituary notice of Prof. H. E. Armstrong in NatuRE of July 24, on p. 149, col. 1, lines 17 and 16 from bottom, for "Sir George Grove" read "Sir William R. Grove". 